Check for updates

Cite this: RSC Adv., 2018, 8, 24866

\section{Synthesis of core-shell $\mathrm{N}-\mathrm{TiO}_{2} \mathrm{CCuO}_{x}$ with enhanced visible light photocatalytic performance $\uparrow$}

\begin{abstract}
Shu Wang, Rufei Huo, Rui Zhang, Yuchuan Zheng, Changjiang Li and Le Pan (DD*
In this paper, a core-shell $\mathrm{N}-\mathrm{TiO}_{2} \mathrm{aCuO}_{x}$ nanomaterial with increased visible light photocatalytic activity was successfully synthesized using a simple method. By synthesizing ammonium titanyl oxalate as a precursor, $\mathrm{N}$-doped $\mathrm{TiO}_{2}$ can be prepared, then the core-shell structure of $\mathrm{N}-\mathrm{TiO}_{2}\left(\mathrm{aCuO}_{x}\right.$ with a catalyst loading of $\mathrm{Cu}$ on its surface was prepared using a precipitation method. It was characterized in detail using XRD, TEM, BET, XPS and $\mathrm{H}_{2}$-TPR, while its photocatalytic activity was evaluated using the probe reaction of the degradation of methyl orange. We found that the core-shell $\mathrm{N}-\mathrm{TiO}_{2}\left(\mathrm{aCuO}_{x}\right.$ nanomaterial can lessen the $\mathrm{TiO}_{2}$ energy band-gap width due to the $\mathrm{N}$-doping, as well as remarkably improving the photo-degradation activity due to a certain loading of $\mathrm{Cu}$ on the surfaces of $\mathrm{N}-\mathrm{TiO}_{2}$ supports. Therefore, a preparation method for a novel N, Cu co-doped $\mathrm{TiO}_{2}$ photocatalyst with a coreshell structure and efficient photocatalytic performance has been provided.
\end{abstract}

Received 28th March 2018 Accepted 30th June 2018

DOI: $10.1039 / \mathrm{c} 8 \mathrm{ra0} 2708 \mathrm{k}$

rsc.li/rsc-advances require nitrogen sources. On this basis, Fang $^{24}$ found that a Ndoped $\mathrm{TiO}_{2}$ photocatalyst could be obtained using ammonium titanyl oxalate as the precursor, and the efficiency of the process was greatly improved.

At the same time, the precious metals that have been reported with $\mathrm{TiO}_{2}$ to improve the photocatalytic performance include precious metals such as $\mathrm{Pt}, \mathrm{Ag}, \mathrm{Ir}, \mathrm{Au}, \mathrm{Ru}, \mathrm{Pd}, \mathrm{Rh}$ and so on, among which there are the most reports about Pt, followed by $\mathrm{Pd}$ and $\mathrm{Au}^{25-28}$ The photocatalytic performance after Pt modification is the best, but comes with a higher cost. Ag modification leads to relatively less toxicity and has a lower cost. Therefore, the preparation of highly active noble metal doped photocatalysts by Ag deposition and modification is considered to be one of the important directions to improve photocatalytic activity in the future. $\mathrm{Cu}, \mathrm{Ag}$ and $\mathrm{Au}$ elements belong to the same group of the periodic table IB, which means they may have a similar catalytic activity in the oxidation colour-fading reaction. However, the catalytic activity of $\mathrm{CuO}_{x}$ was obviously lower than those of $\mathrm{AgO}_{x}$ and $\mathrm{AuO}_{x}$ due to the catalytic reaction on the surface of $\mathrm{CuO}_{x}$ which has been shown to have a higher activation energy in previous research. ${ }^{29-31}$

In this paper, from the perspective of energy utilization and catalytic activity, we composed a new $\mathrm{TiO}_{2}$ compound with $\mathrm{N}$ and $\mathrm{Cu}$ co-doped by a two-step method. When $\mathrm{TiO}_{2}$ was synthesized, $\mathrm{N}$ doping was completed simultaneously using a suitable synthesis in the first step, which is different to the traditional method. There are many benefits to employing the new synthetic method of $\mathrm{N}$-doped $\mathrm{TiO}_{2}$, such as: excellent reproducibility of sample synthesis, a better N-doped effect, and outstanding stability of catalytic activity based on "zero" loss of the $\mathrm{N}$ element. In the second step, the core-shell structure $\mathrm{N}$ $\mathrm{TiO}_{2} @ \mathrm{CuO}_{x}$ catalyst was prepared by a precipitation method.
College of Chemistry and Chemical Engineering, Huangshan University, Huangshan 245041, China. E-mail: panle_hs@163.com

$\dagger$ Electronic supplementary information (ESI) available. See DOI: $10.1039 / \mathrm{c} 8 \mathrm{ra} 02708 \mathrm{k}$

Metallic oxides are important and widely used in catalysis, environmental science, ceramics, electronic devices and materials chemistry. ${ }^{1-4}$ However, there are some disadvantages to
single metallic oxides ${ }^{5-7}$ For example, anatase $\mathrm{TiO}_{2}$ as a photocatalyst has many advantages, such as: cheapness, nontoxicity, stable chemical properties, degradation of organic matter and However, the band gap of $3.2 \mathrm{eV}$ can only respond to UV light with a wavelength less than $387 \mathrm{~nm} .^{\mathbf{1 4 - 1 7}}$ The energy of ultr restricts the application of this photocatalyst to decrease of the band-gap of $\mathrm{TiO}_{2}$ because of the element $\mathrm{N}$. The prepare $\mathrm{N}$-doped $\mathrm{TiO}_{2}$. These methods, without exception, 
The light energy which was absorbed by $\mathrm{N}$ doped $\mathrm{TiO}_{2}$ could be translated into the internal energy which was employed across the high energy barrier mentioned above. Then, their structures were examined with XRD, TEM, BET, and XPS. Lastly, we compared their catalytic activities using methyl orange degradation experiments. Therefore, an $\mathrm{N}, \mathrm{Cu}$ co-doped $\mathrm{TiO}_{2}$ photocatalyst has been synthesized using a simple and low-cost process, and its core-shell structure and efficient photocatalytic performance have been studied.

\section{Results and discussion}

Fig. $\mathrm{S} 1 \uparrow$ displays the concentration of methyl orange as a function of the reaction time over the different amounts of copper oxide in the catalytic system of $\mathrm{TiO}_{2} @ \mathrm{CuO}_{x}$ and $\mathrm{N}-\mathrm{TiO}_{2} @ \mathrm{CuO}_{x}$ catalysts in UV, all wavelengths, and visible light respectively. This shows that the adsorption performance decreased and the catalytic activity increased as the $\mathrm{CuO}_{x}$ loading increased. Considering the above conditions, the total degradation performances of $\mathrm{TiO}_{2} @ 0.1 \mathrm{CuO}_{x}$ and $\mathrm{N}-\mathrm{TiO}_{2} @ 0.1 \mathrm{CuO}_{x}$ showed maximum activities in the respective catalytic systems. Therefore, $0.1 \mathrm{CuO}_{x}$ was chosen in the later text and we do not specifically point out " 0.1 ".

Fig. 1 displays the XRD patterns of the $\mathrm{TiO}_{2}(\mathrm{~A}), \mathrm{N}-\mathrm{TiO}_{2}$ (B), $\mathrm{TiO}_{2} @ \mathrm{CuO}_{x}$ (C) and $\mathrm{N}-\mathrm{TiO}_{2} @ \mathrm{CuO}_{x}$ (D) catalysts. The XRD patterns of the four catalysts all clearly show anatase $\mathrm{TiO}_{2}$ diffraction peaks, while only in the XRD pattern of $\mathrm{TiO}_{2} @ \mathrm{CuO}_{x}$ (C) and $\mathrm{N}-\mathrm{TiO}_{2} @ \mathrm{CuO}_{x}$ (D) catalysts can we find $\mathrm{Cu}_{2} \mathrm{O}$ diffraction peaks. These indicate the amount of $\mathrm{Cu}_{2} \mathrm{O}$ nanoparticles formed when the copper nitrate was deposited on the surface of $\mathrm{TiO}_{2}$ and $\mathrm{N}-\mathrm{TiO}_{2}$.

Fig. 2 shows representative transmission electron microscopy (TEM) images of $\mathrm{TiO}_{2}$ (A), $\mathrm{N}-\mathrm{TiO}_{2}$ (B), $\mathrm{TiO}_{2} @ \mathrm{CuO}_{x}(\mathrm{C})$ and $\mathrm{N}-\mathrm{TiO}_{2} @ \mathrm{CuO}_{x}$ (D) catalysts. The TEM images of the four catalysts all clearly show the core and shell structures in the $\mathrm{TiO}_{2} @ \mathrm{CuO}_{x}$ (C) and $\mathrm{N}-\mathrm{TiO}_{2} @ \mathrm{CuO}_{x}$ (D) catalysts, but not in the $\mathrm{TiO}_{2}$ (A) and $\mathrm{N}-\mathrm{TiO}_{2}$ (B) catalysts.

Fig. 3 displays Ti 2p XPS patterns of the $\mathrm{TiO}_{2}, \mathrm{~N}-\mathrm{TiO}_{2}$, $\mathrm{TiO}_{2} @ \mathrm{CuO}_{x}$ and $\mathrm{N}-\mathrm{TiO}_{2} @ \mathrm{CuO}_{x}$ catalysts. The Ti 2p XPS spectra of $\mathrm{TiO}_{2}$ and $\mathrm{N}-\mathrm{TiO}_{2}$ can be nicely fitted with one component

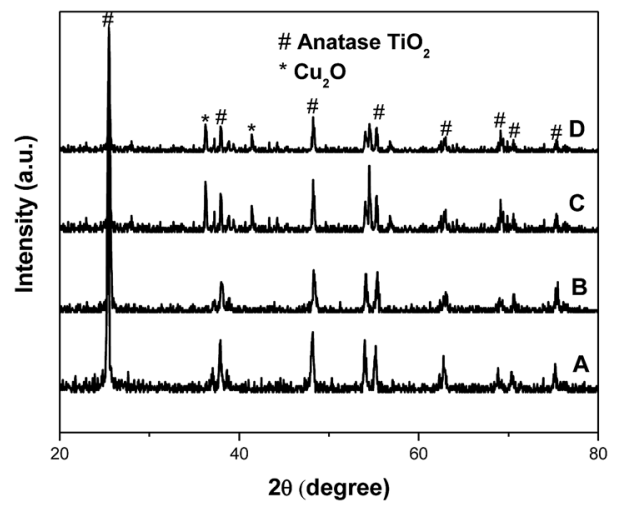

Fig. 1 XRD patterns of the $\mathrm{TiO}_{2}(\mathrm{~A}), \mathrm{N}-\mathrm{TiO}_{2}(\mathrm{~B}), \mathrm{TiO}_{2} \mathrm{aCuO}_{x}(\mathrm{C})$ and $\mathrm{N}-$ $\mathrm{TiO}_{2} \mathrm{aCuO}_{x}(\mathrm{D})$ catalysts.

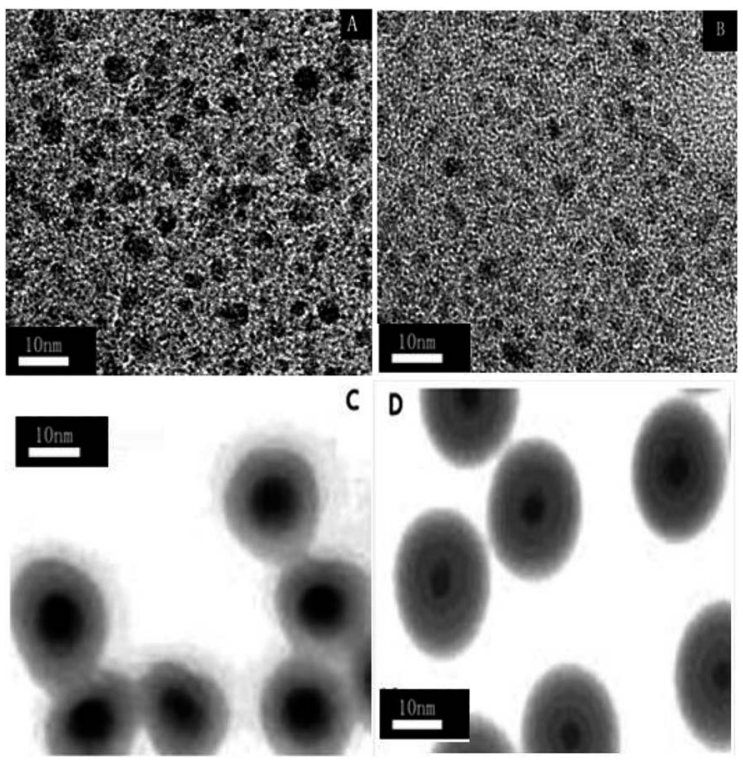

Fig. 2 Transmission electron microscopy (TEM) images of the $\mathrm{TiO}_{2}(\mathrm{~A})$, $\mathrm{N}-\mathrm{TiO}_{2}(\mathrm{~B}), \mathrm{TiO}_{2} \mathrm{CCuO}_{x}(\mathrm{C})$ and $\mathrm{N}-\mathrm{TiO}_{2} \mathrm{aCuO}_{x}(\mathrm{D})$ catalysts.

centring at $458.5 \mathrm{eV}$, which can be attributed to $\mathrm{Ti}^{4+}$ on the surface. ${ }^{32}$ With the $\mathrm{Cu}$ loading on $\mathrm{TiO}_{2}$ and $\mathrm{N}-\mathrm{TiO}_{2}$, the $\mathrm{Ti} 2 \mathrm{p}$ peak shifts from $458.5 \mathrm{eV}$ to $459.0 \mathrm{eV}$. Therefore, we hypothesize that the interaction between $\mathrm{Ti}$ and $\mathrm{Cu}$ on the interface contributes to this shift. While the Ti 2p XPS spectra of $\mathrm{TiO}_{2} @ \mathrm{CuOX}$ and $\mathrm{N}-\mathrm{TiO}_{2} @ \mathrm{CuOX}$ fit with another component centring at $459.0 \mathrm{eV}$, the formation of the chemical bonds increases the binding energy of $\mathrm{Ti}^{17}{ }^{17}$ which can be attributed to the complex species on the surfaces of core-shell structures.

Fig. 4 shows the $\mathrm{Cu} 2 \mathrm{p}_{3 / 2}$ XPS patterns of the $\mathrm{TiO}_{2} @ \mathrm{CuO}_{x}$ and $\mathrm{N}-\mathrm{TiO}_{2} @ \mathrm{CuO}_{x}$ catalysts. Table 1 shows the peak-fitting results of the $\mathrm{Cu}$ XPS spectra. We can observe that the $\mathrm{TiO}_{2} @ \mathrm{CuO}_{x}$ and $\mathrm{N}-\mathrm{TiO}_{2} @ \mathrm{CuO}_{x}$ catalysts both show double peaks which are split in the $\mathrm{Cu} 2 \mathrm{p}_{3 / 2}$ XPS patterns. As the binding energy is almost the same for $\mathrm{Cu}^{0}$ and $\mathrm{Cu}^{+}$in XPS, ${ }^{33}$ we cannot differentiate between the two peaks at low binding energies in the XPS spectra. As the 941-944 eV shake-up ${ }^{34}$ is unique for $\mathrm{Cu}^{2+}$ in XPS spectra, and

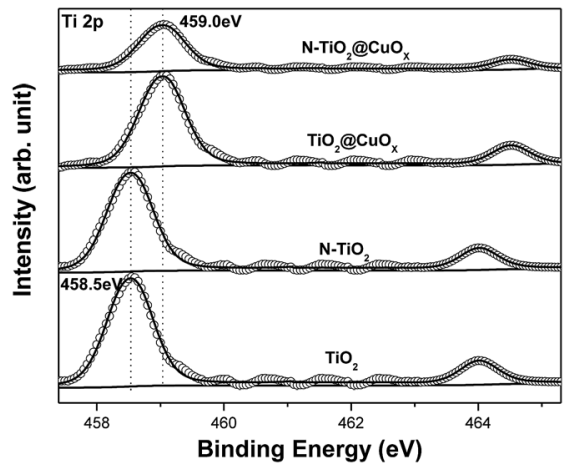

Fig. 3 Ti $2 p$ XPS patterns of the $\mathrm{TiO}_{2}, \mathrm{~N}-\mathrm{TiO}_{2}, \mathrm{TiO}_{2} \mathrm{QCuO}_{x}$ and $\mathrm{N}-$ $\mathrm{TiO}_{2} \mathrm{aCuO}_{x}$ catalysts. Scattered circles and solid lines indicate the experimental data and fitting spectra, respectively. 


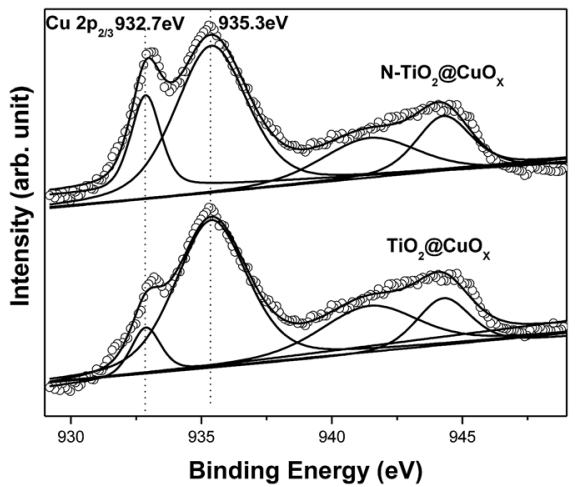

Fig. $4 \mathrm{Cu} 2 \mathrm{p}_{3 / 2}$ XPS patterns of the $\mathrm{TiO}_{2} \mathrm{aCuO}_{x}$ and $\mathrm{N}-\mathrm{TiO}_{2} \mathrm{aCuO}_{x}$ catalysts. Scattered circles and solid lines indicate the experimental data and fitting spectra, respectively.

Table 1 Peak-fitting results of $\mathrm{Cu}$ XPS spectra of the $\mathrm{TiO}_{2}\left(\mathrm{aCuO}_{x}\right.$ and $\mathrm{N}-\mathrm{TiO}_{2} \mathrm{CCuO}_{x}$ catalysts

\begin{tabular}{|c|c|c|c|c|}
\hline \multirow[b]{2}{*}{ Catalyst } & \multicolumn{2}{|c|}{ Component 1} & \multicolumn{2}{|c|}{ Component 2} \\
\hline & $\mathrm{BE}(\mathrm{eV})$ & Fraction & $\mathrm{BE}(\mathrm{eV})$ & Fraction \\
\hline $\mathrm{TiO}_{2} @ \mathrm{CuO}_{x}$ & 932.7 & $9 \%$ & 935.3 & $91 \%$ \\
\hline $\mathrm{N}-\mathrm{TiO}_{2} @ \mathrm{CuO}_{x}$ & 932.7 & $25 \%$ & 935.3 & $75 \%$ \\
\hline
\end{tabular}

the binding energy of $\mathrm{Cu}^{2+}$ increases, we can confirm that it is the $\mathrm{Cu}^{2+}$ that caused the peak at $935.3 \mathrm{eV}$. The difference between the $\mathrm{Cu} 2 \mathrm{p}_{3 / 2}$ XPS spectra of the two samples is great, which indicates the different speciation which exists on their surfaces.

The following conclusions can be reached by analyzing the above results. When the copper nitrate was separately deposited on the surfaces of $\mathrm{TiO}_{2}$ and $\mathrm{N}-\mathrm{TiO}_{2}$, the content of $\mathrm{Cu}^{\circ}$ and $\mathrm{Cu}^{+}$ obtained on the surfaces of $\mathrm{TiO}_{2}$ and $\mathrm{N}-\mathrm{TiO}_{2}$ was consistent with previous XRD results. Furthermore, we cannot find a peak due to $\mathrm{CuO}$ in the XRD patterns, but it is obvious in the XPS patterns. Therefore it can be hypothesized that the $\mathrm{CuO}$ on the surface of the catalysts was amorphous.

The $\mathrm{N}$ 1s XPS peak could be adequately fitted by two components with the $\mathrm{N} 1 \mathrm{~s}$ binding energies at 399.5 and $401.5 \mathrm{eV}$ in Fig. 5. We attribute the binding energy at $401.5 \mathrm{eV}$ to the substitution with $\mathrm{N}$ in $\mathrm{O}-\mathrm{Ti}-\mathrm{N},{ }^{35}$ while we attribute the binding energy at $399.5 \mathrm{eV}$ to doped $\mathrm{N}$ in interstitial lattice sites, which can decrease the band gap from $3.2 \mathrm{eV}$ to $2.4 \mathrm{eV}^{22}$

Fig. 6 and Table 2 show the $\mathrm{N}_{2}$ adsorption-desorption isotherms and textural parameters of $\mathrm{TiO}_{2}, \mathrm{~N}-\mathrm{TiO}_{2}, \mathrm{TiO}_{2} @ \mathrm{CuO}_{x}$ and $\mathrm{N}-\mathrm{TiO}_{2} @ \mathrm{CuO}_{x}$ respectively. The $\mathrm{N}_{2}$ adsorption-desorption isotherms of $\mathrm{TiO}_{2}$ and $\mathrm{N}-\mathrm{TiO}_{2} @ \mathrm{CuO}_{x}$ are similar with $\mathrm{H} 2$ hysteresis loops according to IUPAC, which illustrate that the mesoporous structure exists on the surface of the catalysts. ${ }^{36} \mathrm{We}$ attribute the difference in absorption and desorption mechanisms to the "ink-bottle" pore. ${ }^{37}$ The $\mathrm{N}_{2}$ adsorption-desorption isotherms of $\mathrm{N}^{-\mathrm{TiO}_{2}}$ show that the hysteresis loop is very wide with a high specific surface area and small size. The $\mathrm{N}_{2}$ adsorption-desorption isotherm of $\mathrm{TiO}_{2} @ \mathrm{CuO}_{x}$ shows that the

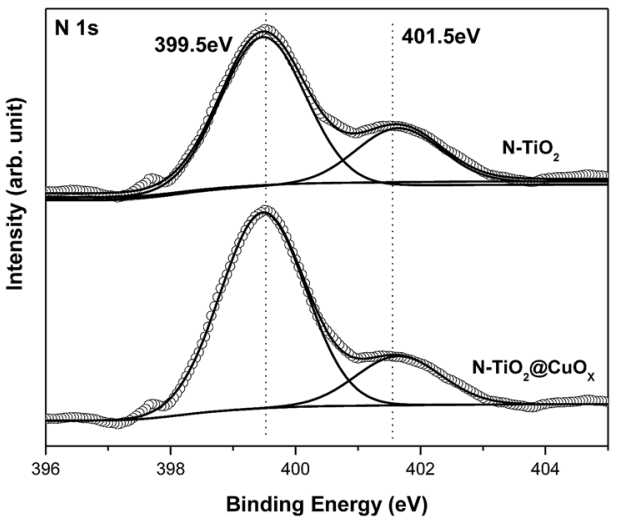

Fig. $5 \mathrm{~N}$ 1s XPS patterns of the $\mathrm{N}-\mathrm{TiO}_{2}$ and $\mathrm{N}-\mathrm{TiO}_{2} \mathrm{CCuO}_{x}$ catalysts. Scattered circles and solid lines indicate the experimental data and fitting spectra, respectively.

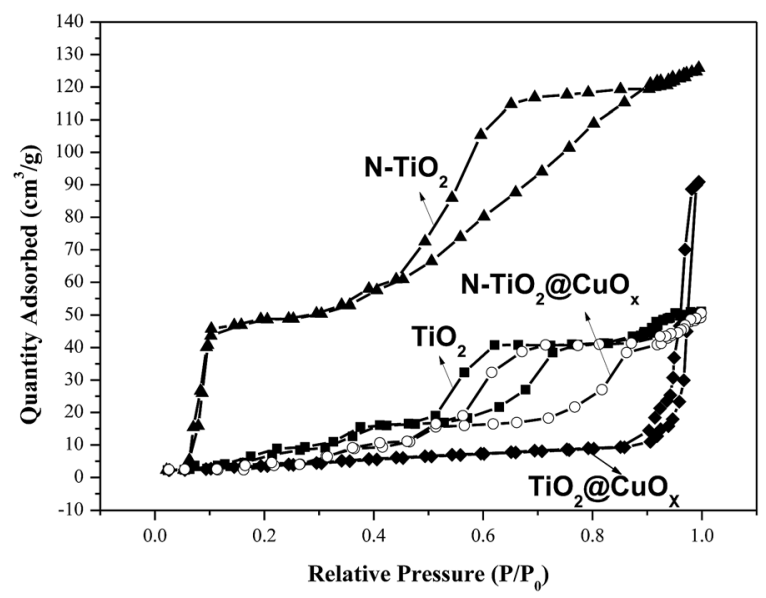

Fig. 6 The $\mathrm{N}_{2}$ adsorption-desorption isotherms for $\mathrm{TiO}_{2}, \mathrm{~N}-\mathrm{TiO}_{2}$, $\mathrm{TiO}_{2}\left(\mathrm{CCuO}_{x}\right.$ and $\mathrm{N}-\mathrm{TiO}_{2} \mathrm{aCuO}_{x}$.

hysteresis loop shifts to the higher relative pressure $\left(P / P_{0}=0.9\right)$ between the $\mathrm{H} 2$ and $\mathrm{H} 3$ hysteresis loops according to the BDDT classification, which illustrates that the macro-pore structure exists on the surface of the support with a low specific surface area and big size.

Fig. $\mathrm{S} 2 \dagger$ shows the concentration of methyl orange as a function of the reaction time over the $\mathrm{TiO}_{2}, \mathrm{~N}-\mathrm{TiO}_{2}, \mathrm{TiO}_{2}$ @$\mathrm{CuO}_{x}$ and $\mathrm{N}-\mathrm{TiO}_{2} @ \mathrm{CuO}_{x}$ catalysts in UV light, all wavelengths and visible light. The degradation properties are composed of two parts, adsorption activity and photocatalytic activity, and

Table 2 Textural parameters of $\mathrm{TiO}_{2}, \mathrm{~N}-\mathrm{TiO}_{2}, \mathrm{TiO}_{2}\left(\mathrm{CCuO}_{x}\right.$ and $\mathrm{N}-$ $\mathrm{TiO}_{2} \mathrm{QCuO}_{x}$

\begin{tabular}{|c|c|c|c|}
\hline Support & $\begin{array}{l}\text { Specific surface } \\
\text { area }\left(\mathrm{m}^{2} \mathrm{~g}^{-1}\right)\end{array}$ & $\begin{array}{l}\text { Pore volume } \\
\left(\mathrm{cm}^{3} \mathrm{~g}^{-1}\right)\end{array}$ & $\begin{array}{l}\text { Pore diameter } \\
(\mathrm{nm})\end{array}$ \\
\hline $\mathrm{TiO}_{2}$ & 38.2 & 0.195 & 22.4 \\
\hline $\mathrm{N}-\mathrm{TiO}_{2}$ & 174 & 0.294 & 15.4 \\
\hline $\mathrm{TiO}_{2} @ \mathrm{CuO}_{x}$ & 16.5 & 0.115 & 62.7 \\
\hline $\mathrm{N}-\mathrm{TiO}_{2} @ \mathrm{CuO}_{x}$ & 29.4 & 0.181 & 48.7 \\
\hline
\end{tabular}




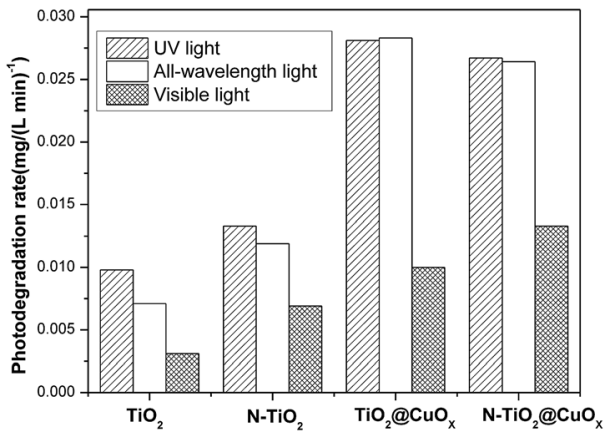

Fig. 7 Photo-degradation rate of the $\mathrm{TiO}_{2}, \mathrm{~N}-\mathrm{TiO}_{2}, \mathrm{TiO}_{2} \mathrm{aCuO}_{x}$ and $\mathrm{N}-\mathrm{TiO}_{2} \mathrm{CCuO}_{x}$ catalysts in UV light, all wavelengths and visible light.

the degradation of methyl orange as the probe reaction was employed to respond to these two parts of the activity under different conditions. The results before the light illumination were characterized as adsorption activity, and after the light illumination as photocatalytic activity. Considering the results of BET and the adsorption and activity performance, we find that the adsorption performance is closely correlated to the specific surface area and size. Among the catalysts, $\mathrm{N}-\mathrm{TiO}_{2}$ has the best adsorption and $\mathrm{TiO}_{2} @ \mathrm{CuO}_{x}$ has the worst, while $\mathrm{N}-\mathrm{TiO}_{2} @ \mathrm{CuO}_{x}$ is close to $\mathrm{TiO}_{2}$ which is in the middle. We can conclude from the results of XPS, TEM and the absorption data that $\mathrm{N}$-doping can effectively improve the absorption by the catalyst, but the core-shell structure may have an adverse effect.

Fig. 7 and 8 display the photo-degradation rate and total degradation rate of the $\mathrm{TiO}_{2}, \mathrm{~N}-\mathrm{TiO}_{2}, \mathrm{TiO}_{2} @ \mathrm{CuO}_{x}$ and $\mathrm{N}$ $\mathrm{TiO}_{2} @ \mathrm{CuO}_{x}$ catalysts in UV light, all wavelengths and visible light. The catalytic activity of $\mathrm{N}-\mathrm{TiO}_{2}$ is much better than that of $\mathrm{TiO}_{2}$ in visible light, and also of $\mathrm{N}-\mathrm{TiO}_{2} @ \mathrm{CuO}_{x}$ and $\mathrm{TiO}_{2} @ \mathrm{CuO}_{x}$. We can make a conclusion that $\mathrm{N}$-doping can effectively reduce the band gap of energy of $\mathrm{TiO}_{2}$ and improve the use of visible light.

Fig. 9 shows the UV-vis diffuse reflection spectra of $\mathrm{N}^{-\mathrm{TiO}_{2}}$ and $\mathrm{N}-\mathrm{TiO}_{2} @ \mathrm{CuO}_{x}$. The $\mathrm{N}-\mathrm{TiO}_{2}$ and $\mathrm{N}-\mathrm{TiO}_{2} @ \mathrm{CuO}_{x}$ catalysts exhibit a pale yellow colour. The UV-vis diffuse reflection spectra of these two catalysts show a continuous and tailing

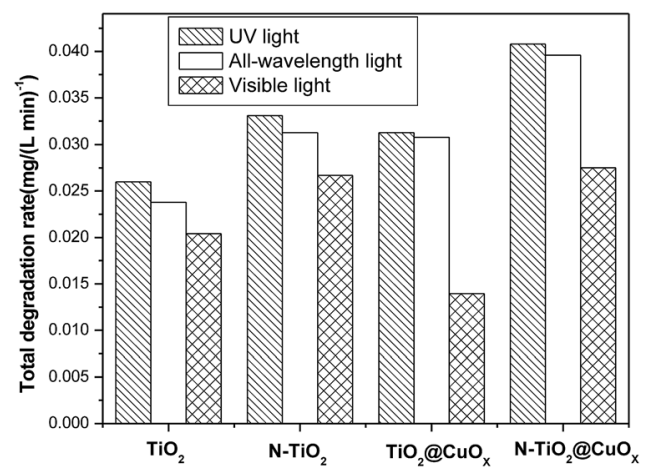

Fig. 8 Total degradation rate of $\mathrm{TiO}_{2}, \mathrm{~N}-\mathrm{TiO}_{2}, \mathrm{TiO}_{2}\left(\mathrm{aCuO}_{x}\right.$ and $\mathrm{N}$ $\mathrm{TiO}_{2} \mathrm{ACuO}_{x}$ catalysts in UV light, all wavelengths and visible light respectively.

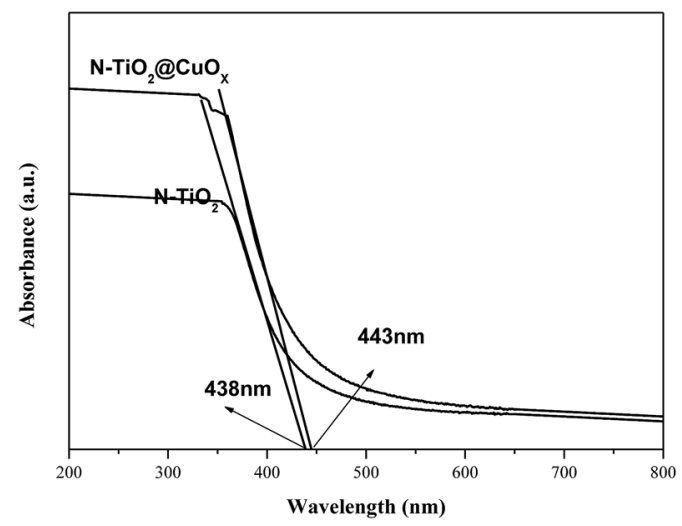

Fig. 9 UV-vis diffuse reflection spectra for the catalysts $\mathrm{N}-\mathrm{TiO}_{2}$ and $\mathrm{N}-\mathrm{TiO}_{2} \mathrm{CCuO}_{x}$.

absorption in the visible region. The band-gap energies of the $\mathrm{N}$ $\mathrm{TiO}_{2}$ and $\mathrm{N}-\mathrm{TiO}_{2} @ \mathrm{CuO}_{x}$ catalysts are 2.83 and $2.80 \mathrm{eV}$, respectively, which were determined by the plot of the modified Kubelka-Munk function $(\alpha h \nu)^{1 / 2}$ versus photon energy assuming indirect transitions. ${ }^{38}$ Based on the above data, we can make a conclusion that $\mathrm{N}$-doping can effectively reduce the band gap of energy of $\mathrm{TiO}_{2}$ in $\mathrm{N}-\mathrm{TiO}_{2}$ and $\mathrm{N}-\mathrm{TiO}_{2} @ \mathrm{CuO}_{x}$ catalysts.

Fig. 10 shows the $\mathrm{H}_{2}$-TPR spectra of the catalysts of $\mathrm{TiO}_{2} @-$ $\mathrm{CuO}_{x}$ and $\mathrm{N}-\mathrm{TiO}_{2} @ \mathrm{CuO}_{x}$. The $\mathrm{H}_{2}$-TPR of $\mathrm{CuO}$ supported on $\mathrm{CeO}_{2}$ has been extensively investigated: ${ }^{39-42} \mathrm{CuO}$ is reduced below $300{ }^{\circ} \mathrm{C}$ and the reduction temperature of different $\mathrm{CuO}$ species on $\mathrm{CeO}_{2}$ follows the order: finely dispersed $\mathrm{CuO}<$ large $\mathrm{CuO}$ crystallites $<$ bulk $\mathrm{CuO}$. Therefore, the reduction peak at $221^{\circ} \mathrm{C}$ is assigned to the reduction of finely dispersed $\mathrm{CuO}$, and that at $258^{\circ} \mathrm{C}$ to the reduction of large $\mathrm{CuO}$ crystallites and bulk $\mathrm{CuO}^{43}$

Considering the results from $\mathrm{H}_{2}$-TPR and the photodegradation performance of $\mathrm{TiO}_{2} @ \mathrm{CuO}_{x}$ and $\mathrm{N}-\mathrm{TiO}_{2} @ \mathrm{CuO}_{x}$ catalysts in UV and all-wavelength light, the activity increases as the size of $\mathrm{CuO}$ decreases on the surface. However, the reason for the activity of $\mathrm{TiO}_{2} @ \mathrm{CuO}_{x}$ being worse than $\mathrm{N}-\mathrm{TiO}_{2} @ \mathrm{CuO}_{x}$ in visible light can be attributed to the decrease in efficiency for visible light.

On the basis of TEM, BET, $\mathrm{H}_{2}$-TPR, XPS, the catalytic activity performance and the stability results, the interfacial structures

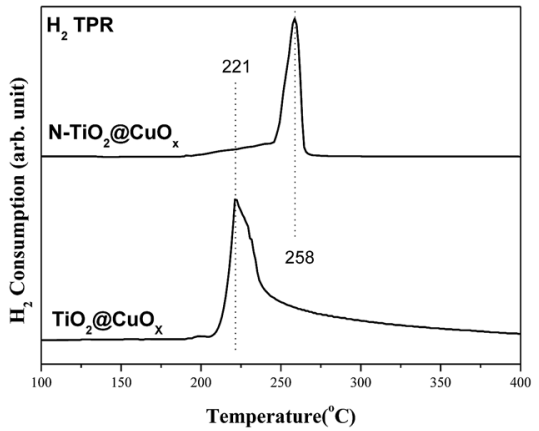

Fig. $10 \mathrm{H}_{2}$-TPR spectra of the catalysts $\mathrm{TiO}_{2} \mathrm{aCuO}_{x}$ and $\mathrm{N}$ $\mathrm{TiO}_{2} \mathrm{OCuO}$. 

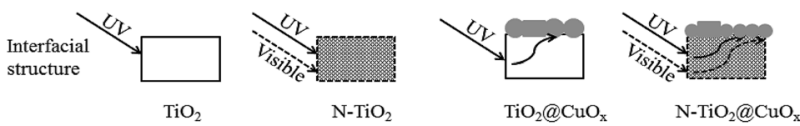

of $\mathrm{TiO}_{2}, \mathrm{~N}-\mathrm{TiO}_{2}, \mathrm{TiO}_{2} @ \mathrm{CuO}_{x}$ and $\mathrm{N}-\mathrm{TiO}_{2} @ \mathrm{CuO}_{x}$ and their responses to different wavelengths of light are schematically illustrated in Fig. 11. These results demonstrate that the

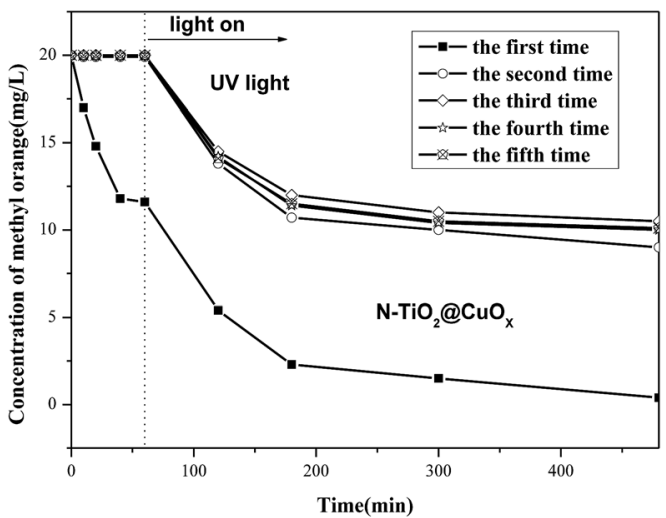

interfacial reaction mechanisms on the surfaces of $\mathrm{TiO}_{2} @ \mathrm{CuO}_{x}$ and $\mathrm{N}^{-} \mathrm{TiO}_{2} @ \mathrm{CuO}_{x}$ are the same. The light energy which was absorbed by $\mathrm{TiO}_{2}$ and $\mathrm{N}$-doped $\mathrm{TiO}_{2}$ is translated into the internal energy which was employed to overcome the energy barrier of the reaction on the $\mathrm{CuO}_{x}$ surface. The difference is simply the wavelengths of light which are responded to by $\mathrm{TiO}_{2}$ and $\mathrm{N}$-doped $\mathrm{TiO}_{2}$.

Fig. 12 shows the stability of $\mathrm{N}^{-\mathrm{TiO}_{2}} @ \mathrm{CuO}_{x}$ in UV light, all wavelengths, and visible light, and obviously shows that there is hardly any absorption performance, although the activity performances are almost unchanged during the 40 hours. We consider that the $\mathrm{N}-\mathrm{TiO}_{2} @ \mathrm{CuO}_{x}$ catalyst is a kind of reusable material to degrade the methyl orange.
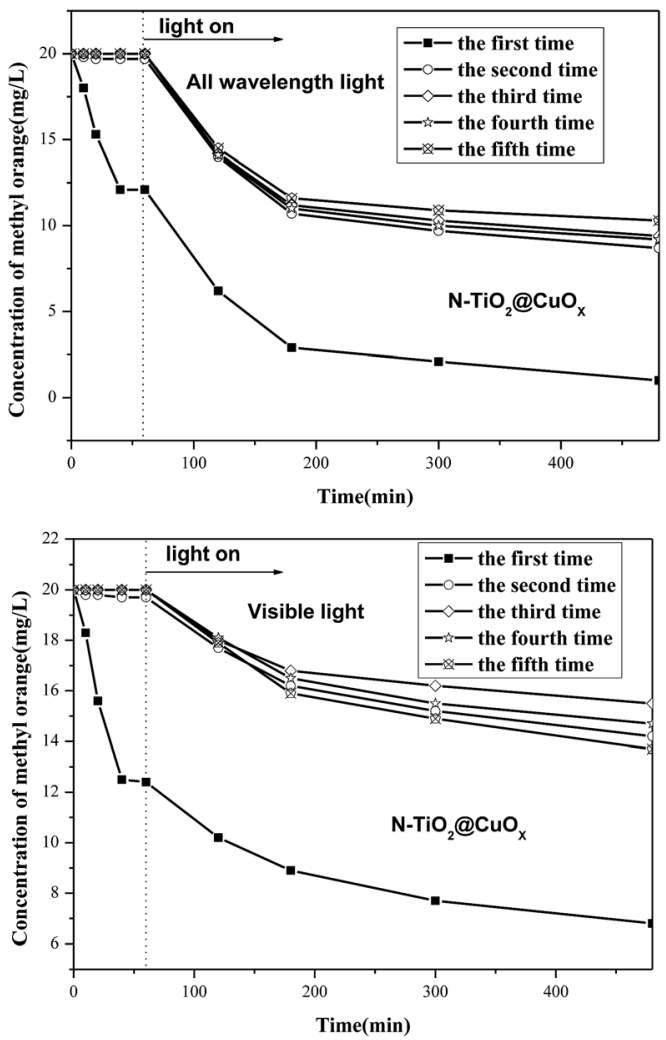

Fig. 12 Stability of the $\mathrm{N}-\mathrm{TiO}_{2}\left(\mathrm{a}_{0.1 \mathrm{CuO}}\right.$ in UV light, all wavelengths, and visible light.

\section{Experimental}

\section{Catalyst preparation}

We prepared two solutions by adding $20.0 \mathrm{~g}$ oxalic acid to $200 \mathrm{~mL}$ distilled water for both, then dripped $10 \mathrm{~mL}$ titanium tetrachloride into both of them dropwise, and stirred them evenly. After the drops were added, we added sodium hydroxide and ammonia solution respectively to adjust the $\mathrm{pH}$ values of the solutions to 8-9. We continuously stirred the above solutions for $8 \mathrm{~h}$, after which white precipitates were produced. After the agitation, we aged them for $8 \mathrm{~h}$, and then filtered out these white precipitates. These white precipitates were washed with distilled water and ethanol several times until there was no chloride in the filtrate, then dried at $70{ }^{\circ} \mathrm{C}$ and calcined for $2 \mathrm{~h}$ at $400{ }^{\circ} \mathrm{C}$ in sequence. These two obtained products were recorded as $\mathrm{TiO}_{2}$ and $\mathrm{N}-\mathrm{TiO}_{2}$, respectively.

The above $\mathrm{TiO}_{2}(5 \mathrm{~g})$ and $\mathrm{N}-\mathrm{TiO}_{2}(5 \mathrm{~g})$ were ground to powders and each was put into a three-neck bottle. Then we added $5 \mathrm{~mL}$ copper nitrate solution $\left(1.06 \mathrm{~mol} \mathrm{~L}^{-1}\right)$ and distilled water to both of them and stirred them at $70{ }^{\circ} \mathrm{C}$ for $30 \mathrm{~min}$. Then we added sodium hydroxide and ammonia solution respectively to adjust the $\mathrm{pH}$ values of the solutions to 8-9 separately, and stirred them at $70{ }^{\circ} \mathrm{C}$ for $24 \mathrm{~h}$. Then we filtered these solids, washed them with distilled water and ethanol several times, dried them at $70{ }^{\circ} \mathrm{C}$ for $12 \mathrm{~h}$, and calcined them in air at $400{ }^{\circ} \mathrm{C}$ for $4 \mathrm{~h}$. These two obtained products were recorded as $\mathrm{TiO}_{2} @$ $\mathrm{CuO}_{x}$ and $\mathrm{N}-\mathrm{TiO}_{2} @ \mathrm{CuO}_{x}$ respectively.

\section{Catalyst characterization}

Powder X-ray diffraction (XRD) patterns were acquired on a Philips X'Pert PRO SUPER X-ray diffractometer with a Nifiltered $\mathrm{Cu} \mathrm{K} \alpha \mathrm{X}$-ray source operating at $40 \mathrm{kV}$ and $50 \mathrm{~mA}$. Xray photoelectron spectroscopy (XPS) measurements were performed on an ESCALAB 250 electron spectrometer using a monochromatized $\mathrm{Al} \mathrm{K} \alpha$ excitation source $(h \nu=1486.6 \mathrm{eV})$. Transmission electron microscopy (TEM) measurements were carried out on a JEOL-2100F transmission electron microscope at an accelerating voltage of $200 \mathrm{kV} . \mathrm{N}_{2}$ adsorption-desorption isotherms (BET) were acquired on a Beckman Coulter SA3100 surface area analyzer, in which the sample was degassed at $300{ }^{\circ} \mathrm{C}$ for $30 \mathrm{~min}$ under a nitrogen atmosphere prior to the measurements. The reduction behaviors of the catalysts were 
measured using $\mathrm{H}_{2}$ temperature-programmed reduction $\left(\mathrm{H}_{2}\right.$ TPR) techniques. UV-vis absorption spectra were recorded using a SolidSpec-DUV-3700 DUV-vis-NIR spectrometer.

\section{Degradation property measurements}

The degradation property is composed of two parts, the adsorption activity and the photocatalytic activity. We employed the degradation of methyl orange as the probe reaction. We

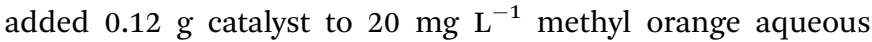
solution $(40 \mathrm{~mL})$, and stirred it for $1 \mathrm{~h}$ whilst avoiding light. We subjected the catalyst to the different wavelengths of irradiation, and took the supernatant to measure the concentration of methyl orange at different time points. The results before the light illumination were characterized as adsorption activity, and after the light illumination as photocatalytic activity.

\section{Conclusions}

A novel $\mathrm{N}, \mathrm{Cu}$ co-doped $\mathrm{TiO}_{2}$ photocatalyst with a core-shell structure has been prepared using a simple method and the structure-adsorption-photo-degradation activity relationships of $\mathrm{TiO}_{2}$ base catalysts were examined using the probe reaction of the degradation of methyl orange. The results suggested that

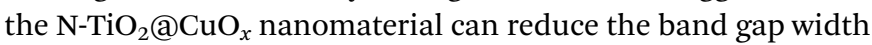
of $\mathrm{TiO}_{2}$ by N-doping. Meanwhile, we found the photodegradation rate of catalysts clearly improved with a certain loading of $\mathrm{Cu}$ on the surfaces of $\mathrm{N}-\mathrm{TiO}_{2}$. Consequently, we synthesized an efficient $\mathrm{N}$-doped $\mathrm{TiO}_{2} @ \mathrm{CuO}_{x}$ photocatalyst with a core-shell structure.

\section{Conflicts of interest}

There are no conflicts to declare.

\section{Acknowledgements}

This work was supported by the National Natural Science Foundation of China (21401065), the Undergraduate Training Programs for Innovation, Entrepreneurship of China (201710375026, 201710375012) and the Natural Science Foundation of Huangshan University (2011xkj014, 2015xkj003).

\section{Notes and references}

1 Q. Hua, T. Cao, X. K. Gu, J. Q. Lu, Z. Q. Jiang, X. R. Pan, L. F. Luo, W. X. Li and W. X. Huang, Angew. Chem., Int. Ed., 2014, 53, 4856-4861.

2 Q. Hua, T. Cao, H. Z. Bao, Z. Q. Jiang and W. X. Huang, ChemSusChem, 2013, 6, 1966-1972.

3 H. B. Tao, L. W. Fan, J. Z. Chen, H. B. Yang, J. J. Gao, J. W. Miao, S. L. Chen and B. Liu, J. Am. Chem. Soc., 2016, 138, 9978-9985.

4 C. Y. Hou, M. W. Zhang, T. S. Kasama, C. Engelbrekt, L. L. Zhang, H. Z. Wang and Q. J. Chi, Adv. Mater., 2016, 28, 4097-4104.

5 N. Serpone, I. Texier, A. V. Emerline, P. Pichat, H. Hidaka and J. Zhao, J. Photochem. Photobiol., A, 2000, 136, 145-246.
6 M. M. Aboelnga and J. W. Gauld, J. Phys. Chem. B, 2017, 121, 6163-6174.

7 A. Dawson and V. K. Prashant, J. Phys. Chem. B, 2001, 105, 960-966.

8 W. Z. Fang, M. Y. Xing and J. L. Zhang, J. Photochem. Photobiol., C, 2017, 32, 21-39.

9 F. Jiang, Z. Zheng, Z. Y. Xu, S. R. Zheng, Z. B. Guo and L. Q. Chen, J. Hazard. Mater., 2006, 134, 94-103.

10 G. Colon, M. C. Hidalgo and J. A. Navio, Appl. Catal., B, 2003, 45, 39-50.

11 P. Mohapatra, S. K. Samantaray and K. Parida, J. Photochem. Photobiol., A, 2005, 170, 189-194.

12 A. Nakajima, H. Obata, Y. Kameshima and K. Okada, Catal. Commun., 2005, 6, 716-720.

13 X. C. Wang, J. C. Yu, P. Liu, X. X. Wang, W. Y. Su and X. Z. Fu, J. Photochem. Photobiol., A, 2006, 179, 339-347.

14 F. Nemati and A. Elhampour, Res. Chem. Intermed., 2016, 42, 7611-7624.

15 J. Fang, F. C. Shi, J. J. Ding, S. T. Xu, J. Bao, Y. S. Ma, J. Q. Jiang, W. P. Zhang and W. X. Huang, J. Phys. Chem. C, 2010, 114, 7940-7948.

16 J. Fang, H. Z. Bao, B. He, F. Wang, D. J. Si, Z. Q. Jiang, Z. Y. Pan, S. Q. Wei and W. X. Huang, J. Phys. Chem. C, 2007, 111, 19078-19085.

17 J. Fang, X. Z. Bi, D. J. Si, Z. Q. Jiang and W. X. Huang, Appl. Surf. Sci., 2007, 253, 8952-8961.

18 R. Asahi, T. Morikawa, T. Ohwaki, K. Aoki and Y. Taga, Science, 2001, 293, 269-271.

19 X. W. Cheng, H. L. Liu, Q. H. Chen, J. J. Li and P. Wang, Electrochim. Acta, 2013, 103, 134-142.

20 H. Irie, Y. Watanabe and K. Hashimoto, J. Phys. Chem. B, 2003, 107, 5483-5486.

21 O. Diwald, T. L. Thompson and T. Zubkov, J. Phys. Chem. B, 2004, 108, 6004-6008.

22 O. Diwald, T. L. Thompson and E. G. Goralski, J. Phys. Chem. $B, 2004,108,52-57$.

23 S. Yin, H. Yamaki and M. Komatsu, J. Mater. Chem., 2003, 13, 2996-3001.

24 J. Fang, F. Wang, K. Qian, H. Z. Bao, H. X. Sun, Z. Q. Jiang and W. X. Huang, J. Phys. Chem. C, 2008, 112, 18150-18156.

25 D. M. Blake, NREL/TP-430-6084, National Renewal Energy Laboratory, Golden, Co, 1994.

26 D. M. Blake, NREL/TP-340-22197, National Renewal Energy Laboratory, Golden, Co, 1997.

27 D. M. Blake, NREL/TP-570-26797, National Renewal Energy Laboratory, Golden, Co, 1999.

28 D. M. Blake, NREL/TP-640-28297, National Renewal Energy Laboratory, Golden, Co, 2002.

29 B. White, M. Yin, A. Hall, D. Le, S. Stolbov, T. Rahman, N. Turro and S. O'Brien, Nano Lett., 2006, 6, 2095-2098.

30 M. F. Luo, J. M. Ma, J. Q. Lu, Y. P. Song and Y. J. Wang, J. Catal., 2007, 246, 52-59.

31 G. Avgouropoulos and T. Ioannides, Appl. Catal., B, 2006, 67, 1-11.

32 J. F. Moulder, W. F. Stickle, P. E. Sobol and K. D. Bomben, Handbook of X-ray Photoelectron Spectroscopy, Perkin-Elmer Corporation, Eden Prairie, MN, 1992. 
33 G. Schon, Surf. Sci., 1973, 35, 96-108.

34 C. C. Chusuei, M. A. Brookshier and D. W. Goodman, Langmuir, 1999, 15, 2806-2808.

35 X. Chen and C. Burda, J. Phys. Chem. B, 2004, 108, 1544615449.

36 X. Yang, Y. H. Wang, L. L. Xu, X. D. Yu and Y. H. Guo, J. Phys. Chem. C, 2008, 112, 11481-11489.

37 H. G. Yu, S. C. Lee, J. G. Yu and C. H. Ao, J. Mol. Catal. A: Chem., 2006, 246, 206-211.

38 I. Motoki, Y. Keiji, K. Tsutomu, O. P. M. Orlando, O. Bunsho and W. Hisanobu, Appl. Catal., B, 2013, 132-133, 39-44.
39 M. F. Luo, J. M. Ma, J. Q. Lu, Y. P. Song and Y. J. Wang, J. Catal., 2007, 246, 52-59.

40 H. B. Zou, X. F. Dong and W. M. Lin, Appl. Surf. Sci., 2006, 253, 2893-2898.

41 T. Caputo, L. Lisi, R. Pirone and G. Russo, Appl. Catal., A, 2008, 348, 42-53.

42 X. L. Tang, B. C. Zhang, Y. Li, Y. D. Xu, Q. Xin and W. J. Shen, Appl. Catal., A, 2005, 288, 116-125.

43 K. Qian, Z. X. Qian, Q. Hua, Z. Q. Jiang and W. X. Huang, Appl. Surf. Sci., 2013, 273, 357-363. 